\title{
Seminavis aegyptiaca sp. nov., a new amphoroid diatom species from estuary epilithon of the River-Nile Damietta Branch, Egypt
}

\author{
Abdullah A. SABer ${ }^{1,4^{*}}$, Ehab F. El-Belely², Ahmed A. El-RefaeY², Ahmed D. \\ El-Gamal ${ }^{2}$, Saúl Blanco ${ }^{3} \&$ Marco CANTONATI ${ }^{4}$
}

\begin{abstract}
${ }^{1}$ Botany Department, Faculty of Science, Ain Shams University, Abbassia Square-11566, Cairo, Egypt; *Corresponding authore-mail: abdullah_elattar@sci.asu.edu.eg

${ }^{2}$ Algae Lab, Botany and Microbiology Department, Faculty of Science, Al-Azhar University, 11448, Cairo, Egypt; e-mails: elbelely@azhar.edu.eg; ahmedabdelkader@azhar.edu.eg;ahmed46da@yahoo.com

${ }^{3}$ Departamento de Biodiversidad y Gestión Ambiental, Facultad de Ciencias Biológicas y Ambientales, Universidad de León, Campus de Vegazana s/n, 24071, León, España; Current address: Laboratorio de diatomología y calidad de aguas. Instituto de Investigación de Medio Ambiente, Recursos Naturales y Biodiversidad. La Serna 58, 24007, León, España

${ }^{4}$ MUSE - Museo delle Scienze, Limnology \& Phycology Section, Corso del Lavoro e della Scienza 3, I-38123 Trento, Italy; e-mail: marco.cantonati@muse.it
\end{abstract}

\begin{abstract}
During a recent floristic-taxonomic study on the algal flora, including diatoms, from the estuary of the Damietta Branch of the Nile in Egypt, an interesting epilithic diatom species belonging to the genus Seminavis (Naviculaceae) was collected and investigated using both light and scanning electron microscopy. This new diatom species shares morphologically some taxonomic diagnostic features with other related taxa such as $S$. insignis, $S$. robusta, and $S$. ventricosa. However, it still differs by having ventral central striae that are shorter and more or less straight in the middle of the smaller frustules to be clearly radiate in the larger ones and then become geniculate and only radiate near the poles, the central raphe endings are externally more distantly spaced than in the similar species, the elongate central nodule is internally less prominent, and the areola density is much denser. Therefore, we here describe it as Seminavis aegyptiaca sp. nov. Hydrochemical analyses revealed that S. aegyptiaca commonly inhabits typical marine, with a weak tendency towards brackish water, habitats. It was found to be tolerant to meso-eutrophic, nutrient-enriched conditions, based on the data available on seasonal concentrations of $\mathrm{N}$ and $\mathrm{P}$ compounds. These findings not only contribute to the inventory of Egyptian diatoms, but also increase our understanding of the autecology and distribution of this relatively poorly-known diatom genus.
\end{abstract}

Key words: benthic diatoms, Egypt, morphotaxonomy, new species, Seminavis, the Nile River

\section{INTRODUCTION}

Seminavis D.G. Mann was first described by MANN in Round et al. (1990), where he separated it from its most closely related genus Amphora Kützing based on the following key taxonomic features: (1) two plate-like, girdle-appressed plastids of unequal size; (2) uniseriate striae with apically-elongate, slit-like areolae; (3) several distinct ultrastructural characters of the raphe sternum and girdle bands. The aforementioned diagnostic characters make Seminavis a member of the family Naviculaceae sensu stricto (Round et al. 1990; Cox 1999), despite the strong dorsiventrality that is the main feature shared with the genus Amphora. Moreover, a cladistic study by Cox \& REID (2004), mainly based on protoplast and frustule characteristics on the generic relationships within the suborder Naviculineae, placed the genus Seminavis within the Navicula subclade. The valve symmetry shift in Seminavis is thus perhaps the most extreme within the family Naviculaceae, leading not only to the development of amphoroid shapes but also involving a change in the organization of cell division and valve ontogeny (Round et al. 1990).

During the last three decades, many taxonomic studies were carried out on the genus Seminavis, resulting in the description or transfer of several species (e.g., DANIELIDIS \& MANN 2002, 2003; DANIELIDIS et al. 2006; GARCIA 2007; WACHNICKA \& GAISER 2007; TALGATTI et al. 2017). In parallel, certain taxa in closely allied genera, e.g. Cymbella C.A. Agardh, underwent in-depth taxonomic revision. For instance, TALgatTi et al. (2014) studied the type material of Cymbella (Encyonema) grossestriata var. recta Frenguelli from Argentina and 
fresh specimens collected from southern Brazil, and proposed the newly described taxon Seminavis norae (Metzeltin, Lange-Bertalot et García-Rodríguez) Talgatti et Torgan because it shared the key characteristics of the genus Seminavis. Twenty-three species have been described in the genus Seminavis so far, in particular thanks to the significant taxonomic work over the last years. From the molecular and phylogenetic standpoints, little is known about the evolutionary position of these taxa. However, BRUdER \& MEDLIN (2008) suggested that the genus Seminavis is monophyletic in origin, and had arisen from the Navicula sensu stricto group. Ecologically, Seminavis mainly inhabits brackish and marine habitats (GUIRY \& GUIRY 2019).

Considerable morphotaxonomic studies carried out on the diatom flora of different Egyptian inland-water habitats, including the main basin and branches of the Nile River (e.g., FogEd 1980; ShAABAN 1994; HAMED 2008; SHAABAN et al. 2012; EL-OTIFY \& IsKAROs 2015; ABDel-SATAr et al. 2017; EL-ShEeKh et al. 2018), did not use scanning electron microscopy (SEM), thus unintentionally neglecting ultrastructural details which play a crucial role in accurate species delimitation. As a consequence, very little information is available for Egypt on the diversity and autecology of diatoms belonging to Seminavis and other morphologically similar amphoroid taxa [e.g., Seminavis strigosa (Hustedt) Danieledis et Economou-Amilli as cited in DANIELIDIS \& MANN (2003), recorded under the name Amphora strigosa Hustedt in the desert springs of Ayun Musa and Wadi Islet in the Sinai Peninsula, and Seminavis robusta D.B. Danielidis et D.G. Mann - originally Amphora angusta var. ventricosa (W. Gregory) Cleve - that was recently reported by SALEH (2009) from the desert inland saline spring 'Ain El-Araes' in the Siwa Oasis (Western Desert of Egypt) during her recent monographic study on the order Naviculales in Egypt].

In this paper, using both light and scanning electron microscopy, we describe a new species within the genus Seminavis collected from the epilithon of the estuary of the Damietta Branch (the Nile River, Egypt), during our recent in-depth floristic-taxonomic and bioassessment studies on the algal communities in this pivotal but highly-impacted habitat.

\section{Materials ANd Methods}

Study site. The Damietta Branch is one of the two main branches of the Nile River, splitting North of Cairo and extending to the East over a distance exceeding $240 \mathrm{~km}$ until reaching the Mediterranean Sea. It has an average width of about $280 \mathrm{~m}$ and a depth ranging between 12 and $20 \mathrm{~m}$. It is dammed ca. $20 \mathrm{~km}$ inland of the river mouth by an artificial dam known as Faraskur Dam Barrage (KHEDR 1998), forming the estuary (Fig. 1). Along its main basin, the Damietta Branch serves as an important water resource for agricultural, domestic, and industrial activities (NeGM et al. 2017). However, this vital water artery and its estuary are negatively influenced by fish farming, in addition to wastewater and agricultural discharges (Elrefaey et al. 2017). Sampling sites along the estuary were arranged towards the Mediterranean Sea as follows: site 1 ( $\left.31^{\circ} 24^{\prime} 54.8^{\prime \prime} \mathrm{N}, 31^{\circ} 48^{\prime} 17^{\prime \prime} \mathrm{E}\right)$, site 2 ( $\left.31^{\circ} 25^{\prime} 29.5^{\prime \prime} \mathrm{N}, 31^{\circ} 48^{\prime} 4.6^{\prime \prime} \mathrm{E}\right)$, site $3\left(31^{\circ} 26^{\prime} 41.2^{\prime \prime} \mathrm{N}, 31^{\circ} 47^{\prime} 39.2^{\prime \prime} \mathrm{E}\right)$, site $4\left(31^{\circ} 27^{\prime} 42^{\prime \prime} \mathrm{N}\right.$, $\left.31^{\circ} 48^{\prime} 7.8^{\prime \prime} \mathrm{E}\right)$, site $5\left(31^{\circ} 28^{\prime} 31.6^{\prime \prime} \mathrm{N}, 31^{\circ} 49^{\prime} 29.7^{\prime \prime} \mathrm{E}\right)$, and site 6 (31 $\left.311^{\prime} 35.6^{\prime \prime} \mathrm{N}, 31^{\circ} 50^{\prime} 38.3 " \mathrm{E}\right)$.

Diatom sampling, preparation, and identification. Thirty diatom samples (epilithon), on which this study is based, were seasonally collected starting from April $28^{\text {th }} 2015$ (spring season of 2015) to April $27^{\text {th }} 2016$ (spring of 2016), from six different localities along the estuary of the River-Nile Damietta branch during our recent in-depth floristic-taxonomic study, following the European standard methods for sampling diatoms in running waters (EN 15708 2009). Samples were treated with hydrogen peroxide (33\%) and hydrochloric acid (37\%), to remove organic matter. After several rinses in distilled water, the diatoms were mounted with Naphrax ${ }^{\circledR}$, a synthetic mounting medium with a high refractive index of 1.74. Light microscope (LM) observations were conducted using a Zeiss Axioskop 2 microscope (Zeiss, Jena, Germany) equipped with phase-contrast and with an Axiocam digital camera. Scanning electron microscopy (SEM) observations were made at the MUSE - Museo delle Scienze, Trento, Italy using a LEO XVP scanning electron microscope (Carl Zeiss SMT Ltd., Cambridge, UK) at high vacuum on gold-coated prepared material. Measurements on at least 30 different specimens representative of the size-diminution series were made to obtain ranges and averages of the morphological and ultrastructural features. Diatom micrograph images were arranged in plates with Adobe Photoshop CS6. Permanent mounts (including the holotype shown in bold in the list below) were deposited at both Algae Lab, Botany and Microbiology Department, Faculty of Science, Al-Azhar University, Cairo, Egypt, and the Phycology Unit (No. 341), Botany Department, Faculty of Science, Ain Shams University; Thiers 2018), Cairo, Egypt

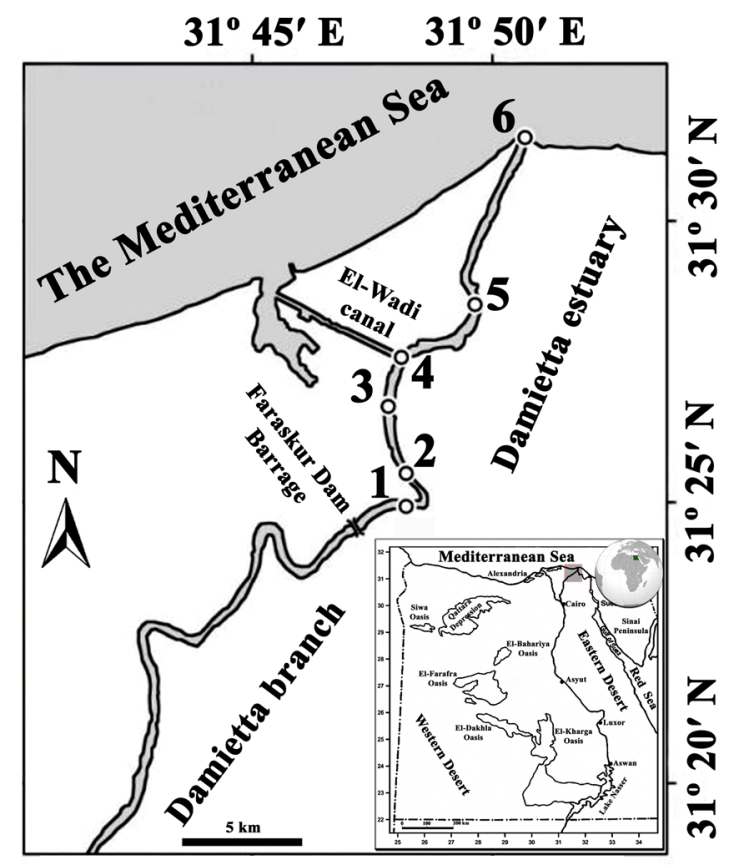

Fig.1. Location of the sites where Seminavis aegyptiaca sp. nov. was sampled. 
Table 1. Average (minimum - maximum) values for selected chemical and physical variables measured at sites where Seminavis aegyptiaca sp. nov. was collected.

\begin{tabular}{|c|c|}
\hline Parameters & Average (min - max) \\
\hline Temperature $\left({ }^{\circ} \mathrm{C}\right)$ & $23.5(15.9-34.4)$ \\
\hline $\mathrm{pH}$ & $7.89(6.19-8.46)$ \\
\hline Total alkalinity $\left(\mathrm{mg} \cdot \mathrm{l}^{-1}\right)$ & $224.8(145-385)$ \\
\hline Conductivity (mS.cm $\left.{ }^{-1}\right)$ & $42.79(27.7-58)$ \\
\hline T.D.S. $\left(\right.$ g. $\left.1^{-1}\right)$ & $28.6(17.7-40.6)$ \\
\hline $\mathrm{Na}^{+}\left(\mathrm{g} .1^{-1}\right)$ & $9.56(5.2-17)$ \\
\hline $\mathrm{K}^{+}\left(\mathrm{mg} \cdot \mathrm{l}^{-1}\right)$ & $110.53(60-360)$ \\
\hline $\mathrm{Ca}^{2+}\left(\mathrm{mg} \cdot 1^{-1}\right)$ & $490.46(240.6-761)$ \\
\hline $\mathrm{Mg}^{2+}\left(\mathrm{mg} \cdot \mathrm{l}^{-1}\right)$ & $295.41(111-1336.5)$ \\
\hline $\mathrm{Cl}^{-}\left(\mathrm{g} . \mathrm{l}^{-1}\right)$ & $13.83(1.76-19.72)$ \\
\hline $\mathrm{SO}_{4}^{2-}\left(\mathrm{mg} \cdot \mathrm{l}^{-1}\right)$ & $1601.5(975-2404)$ \\
\hline $\mathrm{HCO}_{3}^{-}\left(\mathrm{mg} \cdot 1^{-1}\right)$ & $213.18(102-385)$ \\
\hline $\mathrm{CO}_{3}^{2-}\left(\mathrm{mg} \cdot \cdot^{-1}\right)$ & $12.63(4.8-43.2)$ \\
\hline $\mathrm{NO}_{2}^{-}\left(\mu \mathrm{g} \cdot 1^{-1}\right)$ & $124(7-655)$ \\
\hline $\mathrm{NO}_{3}^{-}\left(\mu \mathrm{g} \cdot 1^{-1}\right)$ & $162(60-300)$ \\
\hline $\mathrm{NH}_{4}^{+}\left(\mu \mathrm{g} \cdot \mathrm{l}^{-1}\right)$ & $5361(34-19720)$ \\
\hline $\operatorname{SRP}\left(\mu \mathrm{g} \cdot 1^{-1}\right)$ & $204(30-450)$ \\
\hline $\mathrm{SiO}_{2}\left(\mathrm{mg} \cdot \mathrm{l}^{-1}\right)$ & $1.26(0.2-3.89)$ \\
\hline $\mathrm{Cu}\left(\mu \mathrm{g} .1^{-1}\right)$ & $27.8(1-244)$ \\
\hline $\mathrm{Zn}\left(\mu \mathrm{g} .1^{-1}\right)$ & $23.9(17-284)$ \\
\hline $\mathrm{Al}\left(\mu \mathrm{g} .1^{-1}\right)$ & $10.1(6-103)$ \\
\hline $\mathrm{Ba}\left(\mu \mathrm{g} .1^{-1}\right)$ & $10.6(5-30)$ \\
\hline $\operatorname{Cr}\left(\mu \mathrm{g} .1^{-1}\right)$ & $8.3(3-44)$ \\
\hline $\mathrm{Pb}\left(\mu \mathrm{g} .1^{-1}\right)$ & $4.6(3-51)$ \\
\hline
\end{tabular}

under accession numbers: PBA-DIAT 1501-1518, 1537-1554, 1573-1590, 1609-1626, 1645-1662. The terminology for valve morphology is based on Round et al. (1990).

Hydrochemical characterization. Water sampling for the hydrochemical analyses was conducted using polyethylene bottles which had been previously cleaned with ultrapure water and superpure nitric acid (1\%). Water temperature $\left({ }^{\circ} \mathrm{C}\right), \mathrm{pH}$, electrical conductivity $\left(\mathrm{EC}, \mathrm{mS} . \mathrm{cm}^{-1}\right)$, and total dissolved solids (TDS, g. $1^{-1}$ ) were measured in situ using the calibrated portable Temp/pH/EC/T.D.S. HANNA HI 991301 meter. Total alkalinity, major ions and nutrients were analyzed following standard procedures and methods (CLESCERI et al. 2000). Concentrations of major ions, including sodium $\left(\mathrm{Na}^{+}\right)$, potassium $\left(\mathrm{K}^{+}\right)$, calcium $\left(\mathrm{Ca}^{2+}\right)$ and magnesium $\left(\mathrm{Mg}^{2+}\right)$, were measured using ionic chromatography (ICS 1500 Dionex Corp.). Bicarbonate $\left(\mathrm{HCO}_{3}^{-}\right)$, carbonate $\left(\mathrm{CO}_{3}{ }^{2-}\right)$, chloride $\left(\mathrm{Cl}^{-}\right)$ and sulphate $\left(\mathrm{SO}_{4}^{2-}\right)$ concentrations were determined according to ChAPMAN \& PRATT (1978). Nutrient concentrations, namely nitrite $\left(\mathrm{NO}_{2}^{-}\right)$, nitrate $\left(\mathrm{NO}_{3}^{-}\right)$, ammonium $\left(\mathrm{NH}^{+}\right)$and soluble reactive phosphorus (SRP), were analysed by molecular absorption spectrometry and silica ( as $\mathrm{SiO}_{2}$ ) was estimated by the molybdosilicate method (CLESCERI et al. 2000).

\section{Results}

Seminavis aegyptiaca A.A. Saber, El-Belely, El-Refaey, El-Gamal, Blanco et Cantonati sp. nov. (Figs 2-10, 11-17)

Light microscopy (Figs 2-10): Valves lanceolate to rhombic-lanceolate, with more or less obtusely rounded ends. Valve length (27.5) 30-75 $\mu \mathrm{m}$, valve width 7.5-10.0 $\mu \mathrm{m}$. Dorsal margin distinctly convex. Ventral margin straight, particularly in small frustules (Figs 2-3), to slightly convex in the larger specimens (Figs 4-9). Length-to-breadth ratio ca. 5.0-7.5. The axial area is almost two times wider on the dorsal side than on the ventral one, with a central roundish expansion on the ventral side, particularly in the larger valves. The axial area is separated from the ventral side and the gibbous dorsal part by grooves, which in LM have the appearance of dark lines running along the raphe. The raphe is straight, running parallel to the ventral margin, and ventrally displaced with respect to the midline of the valve. The central raphe endings are slightly expanded and deflected ventrally and relatively close to each other (Figs 4, 6), while the terminal raphe fissures are hooked dorsally. The dorsal striae are more or less radiate in the central part of the valve, (16) 17-19 in $10 \mu \mathrm{m}$, and becoming denser, 19-21 in $10 \mu \mathrm{m}$, near the apices. The ventral striae are shorter and more or less straight in the middle of the smaller specimens to become clearly radiate in the larger ones, then become geniculate and only radiate near the poles, (14) $15-17$ in $10 \mu \mathrm{m}$ at the valve center, much denser and relatively parallel at the poles, 19-21 in $10 \mu \mathrm{m}$ near the apices. The cingulum is simple and unornamented (Fig. 10).

Scanning electron microscopy (Figs 11-14 external views, Figs 15-17 internal views): The valve face is curving into a deep dorsal mantle whilst the ventral mantle is reduced. Externally, the stria areolae in general have the typical Seminavis morphology with uniseriate, apically-elongate, slit-like openings (Figs 11-13). Areola density $(n=25)$ is $55-60$ in $10 \mu \mathrm{m}$. The ridge on which the raphe runs is prominent, and slightly dorsally-bent near the apices (Figs 11-12). The central raphe endings are slightly expanded and deflected to the ventral side, and close to each other (Fig. 13). The valvocopula (Figs 14-15) is composed of three plain and unornamented bands, first being much wider, the second reduced to a small ligulate segment occupying the gaps left at poles by the ends of band I (Fig. 15), and the third one being a narrow abvalvar element (Fig. 14). Internally, the valve structure in general resembles that of all other Seminavis species. The internal areola openings are also slit-like 
(Figs 15-17). The raphe is positioned within a straight rib and slightly dorsally-bent near the apices (Figs 15-16). The central raphe endings are placed within a small, elongate and markedly less prominent nodule (Fig. 16). The raphe branches end apically in an extended, ventrally bent, horseshoe-like helictoglossa. A single row of simple pores is present beyond the helictoglossa at both valve apices (Fig. 17).

Etymology: The specific epithet refers to the Latin name of Egypt, Aegyptus, to highlight the discovery of this new diatom species in this country.

Holotype: The original material of Seminavis aegyptiaca sp. nov. (slide and suspension of prepared material) was deposited in the collections of the Phycology Unit (No. 341), Botany Department, Faculty of Science, Ain Shams University in Cairo (Egypt) (CAIA), accession code: PBA-DIAT 1501. This material, partially shown here in Figs 2-10, was collected by Ahmed A. El-Refaey on April $28^{\text {th }} 2015$.

Isotypes: Diatom collection of the MUSE - Museo delle Scienze, Trento, Italy: cLIM004 DIAT 3515 (including a diatom mount, and an aliquot of cleaned material); Botanischer Garten und Botanisches Museum BerlinDahlem, Zentraleinrichtung der Freien Universität Berlin, Germany (B): B 400044891 (slide) and B 40 0044892 (cleaned material). It was also registered on the PhycoBank.

Registration: http://phycobank.org/102069

Type locality: Estuary epilithon of the River-Nile Damietta Branch $\left(31^{\circ} 24^{\prime} 54.8^{\prime \prime} \mathrm{N}, 31^{\circ} 48^{\prime} 17^{\prime \prime} E\right.$, elevation $2.6 \mathrm{~m}$ a.s.1.).

Ecology and co-occurring diatom species: Seminavis aegyptiaca sp. nov. was mostly found in the estuary epilithon of the River-Nile Damietta branch (Egypt) with an average relative abundance $>5 \%$ throughout the whole study period. These localities were characterized by warm, circumneutral to moderately alkaline waters with very high conductivity (water temperature: 15.9-34.4 ${ }^{\circ} \mathrm{C}$; $\mathrm{pH}$ : 6.19-8.46, average: 7.89 ; conductivity: 27.7-58.0 mS.cm ${ }^{-1}$; average total dissolved salts: 28.58 g. $1^{-1}$. In general, $S$. aegyptiaca seems to prefer typical marine habitats rich in sodium-chloride and sulphate salts, with a weak tendency to expand towards brackish waters. Regarding the trophic status, the estuary of the River-Nile Damietta branch can be classified as a eutrophic habitat based on $\mathrm{N}$ (seasonal average values of $\mathrm{NO}_{2}^{-}, \mathrm{NO}_{3}^{-}$, and $\mathrm{NH}_{4}^{+}$were 124, 162, and 5361 $\mu \mathrm{g} .1^{-1}$, respectively) and P (SRP up to $450 \mu \mathrm{g} . \mathrm{l}^{-1}$ ) concentrations. $\mathrm{Cu}, \mathrm{Zn}, \mathrm{Al}, \mathrm{Ba}, \mathrm{Cr}$, and $\mathrm{Pb}$ were the heavy elements having high concentrations due to different human impacts (including agriculture) highly affecting the estuary (Check Table 1 for more details). Noticeably, some of the localities where $S$. aegyptiaca was found were contaminated by motor oils, gasoline, and solid wastes, in addition to being influenced by fish farming. Therefore, it can be concluded that this diatom species is tolerant to different types of pollution.

The diatom species most common $(>20 \%)$ in the slides in which $S$. aegyptiaca were recorded: Cyclotella stylorum Brightwell, Achnanthes brevipes var. intermedia (Kützing) Cleve, Fallacia sp. Stickle et D.G. Mann, Halamphora coffeaeformis (Agardh) Z. Levkov, Navicula tripunctata (O.F. Müller) Bory, Nitzschia clausii Hantzsch, Nitzschia frustulum (Kützing) Grunow, Nitzschia gracilis Hantzsch, Nitzschia kurzeana Rabenhorst, Opephora sp. Petit, Psammodiscus nitidus (W. Gregory) Round et D.G. Mann, and Tabularia fasciculata (C. Agardh) D.M. Williams et Round.

\section{Discussion}

In this study, Seminavis aegyptiaca sp. nov. is assigned to the genus Seminavis by virtue of possessing all key diagnostic features of this genus, particularly the valve morphology and details of the axial area, raphe, and areola construction (Round et al. 1990; DANIELIDIS \& MANN 2002, 2003). The species most similar to ours are Seminavis insignis Álvarez-Blanco et S. Blanco, $S$. robusta, and S. ventricosa (W. Gregory) M. GarciaBaptista. Seminavis aegyptiaca can be distinguished from the aforementioned taxa, and others in this poorly investigated genus, by having (1) a much higher areola density; (2) central ventral striae being shorter and more or less straight in the middle of the smaller frustules to be clearly radiate in the larger ones, and then becoming geniculate and only radiate near the poles; (3) internally, the small, elongate central nodule is clearly less prominent; (4) the central raphe endings are externally more distantly spaced than in the mentioned species (Figs 2-17; Table 2). Additionally, all these morphologically similar taxa can be separated based on other taxonomic features. As regards $S$. insignis, (1) its valve width is narrower than $S$. aegyptiaca (5.0-7.5 $\mu \mathrm{m}$ vs. 7.5-10 $\mu \mathrm{m}$, respectively), (2) the central raphe endings are deflected dorsally whilst in S. aegyptiaca they are slightly expanded, more distant, and deflected to the ventral side, (3) the dorsal striae are parallel in the central part, 20-26 in $10 \mu \mathrm{m}$, clearly radiate, and much denser at the poles, $24-28$ in $10 \mu \mathrm{m}$ (while $S$. aegyptiaca has radiate dorsal striae in the valve centre, $17-19$ in $10 \mu \mathrm{m}$, and striae are becoming much denser, 19-21 in $10 \mu \mathrm{m}$, near the apices), (4) the ventral striae are much denser (19-23 in $10 \mu \mathrm{m}$ at the valve centre and $22-26$ in $10 \mu \mathrm{m}$ at the poles $v s .15-17$ in $10 \mu \mathrm{m}$ at the valve middle and $19-21$ in $10 \mu \mathrm{m}$ near the apices in S. aegyptiaca), and (5) the areola density is much lower (48-52 in $10 \mu \mathrm{m})$.

Another very similar species is Seminavis robusta. However, it differs in the arrangement of the ventral striae, i.e. S. robusta has distinctly radiate ventral striae in the valve centre whilst in S. aegyptiaca the ventral striae are more or less straight in the centre of smaller frustules to be clearly radiate in larger ones. Additionally, 

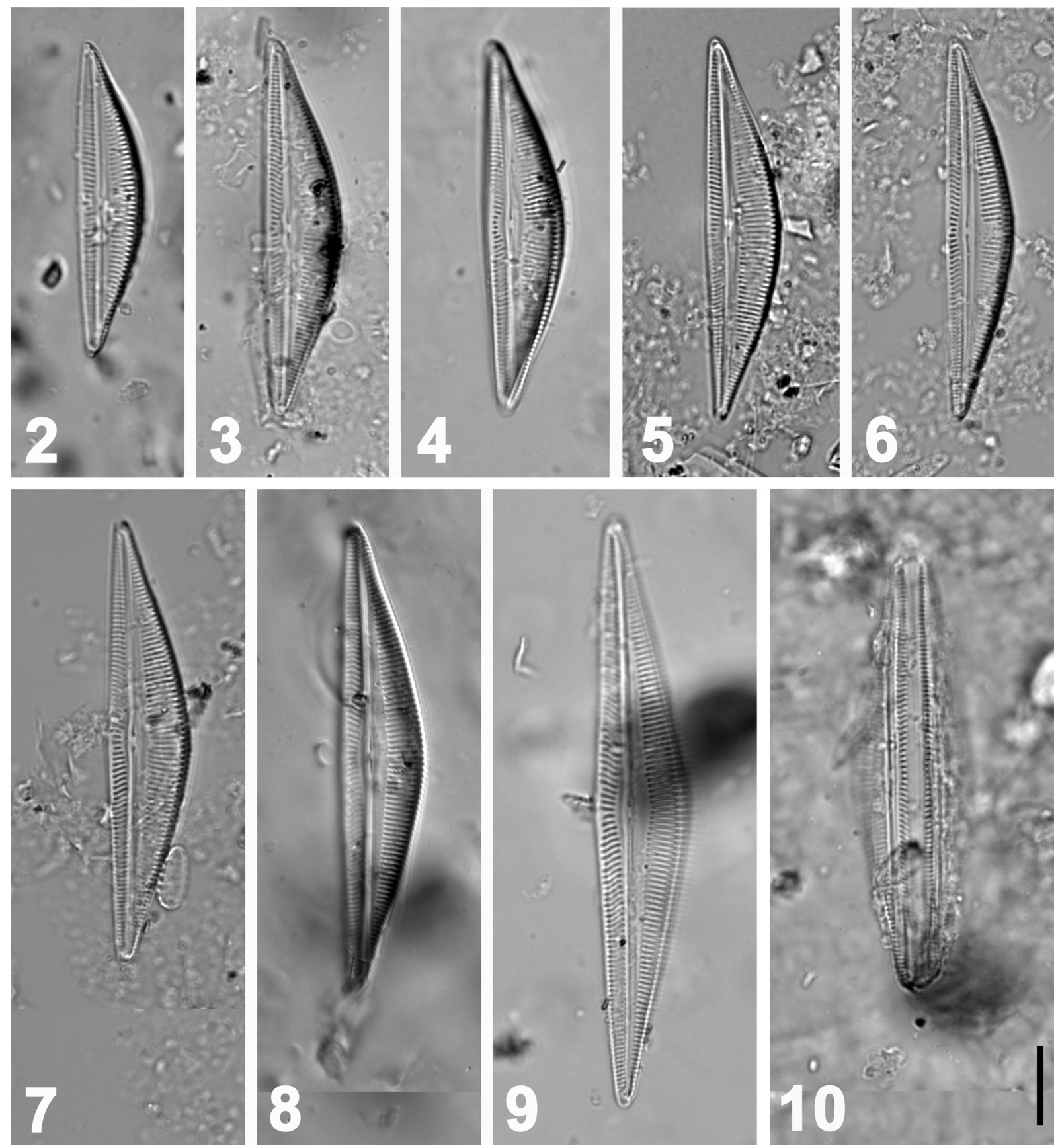

Figs 2-10. Light micrographs of Seminavis aegyptiaca sp. nov., showing the valve variability and girdle view of the holotype population. Scale bar $10 \mu \mathrm{m}$

the raphe ridge is internally bearing the central slits on a longitudinal thickening. This key taxonomic feature is absent in $S$. aegyptiaca, which has a distinctly elongate and less prominent central nodule. Finally, the areola density in S. robusta (as it results from our own measurement made on the SEM image Fig. 50 in the original paper published by DANIELIDIs \& MANN 2002) is much lower than that found in S. aegyptiaca (46-50 in $10 \mu \mathrm{m}$ vs. 55-60 in $10 \mu \mathrm{m})$.

The last morphologically allied species is Seminavis ventricosa which is distinguished from $S$. aegyptiaca by having (1) larger frustules (51.5-101 $\mu \mathrm{m})$; (2) evidently drawn-out valve apices; (3) central raphe endings deflected ventrally but with central pores pointing towards opposite directions; (4) central part of the raphe entering a narrow 'gorge' before opening out again near the raphe endings; (5) much lower dorsal and ventral stria densities ( $S$. ventricosa has $10-12.8$ in 10 $\mu \mathrm{m}$ for dorsal striae and 10-12.1 in $10 \mu \mathrm{m}$ for ventral striae); the central dorsal stria that is usually missing —at least on the adaxial side - or reduced, not reaching the axial area; (6) the dorsal side of the axial area that is wider internally than externally and that combines with the transapical costae to form small chambers at the 

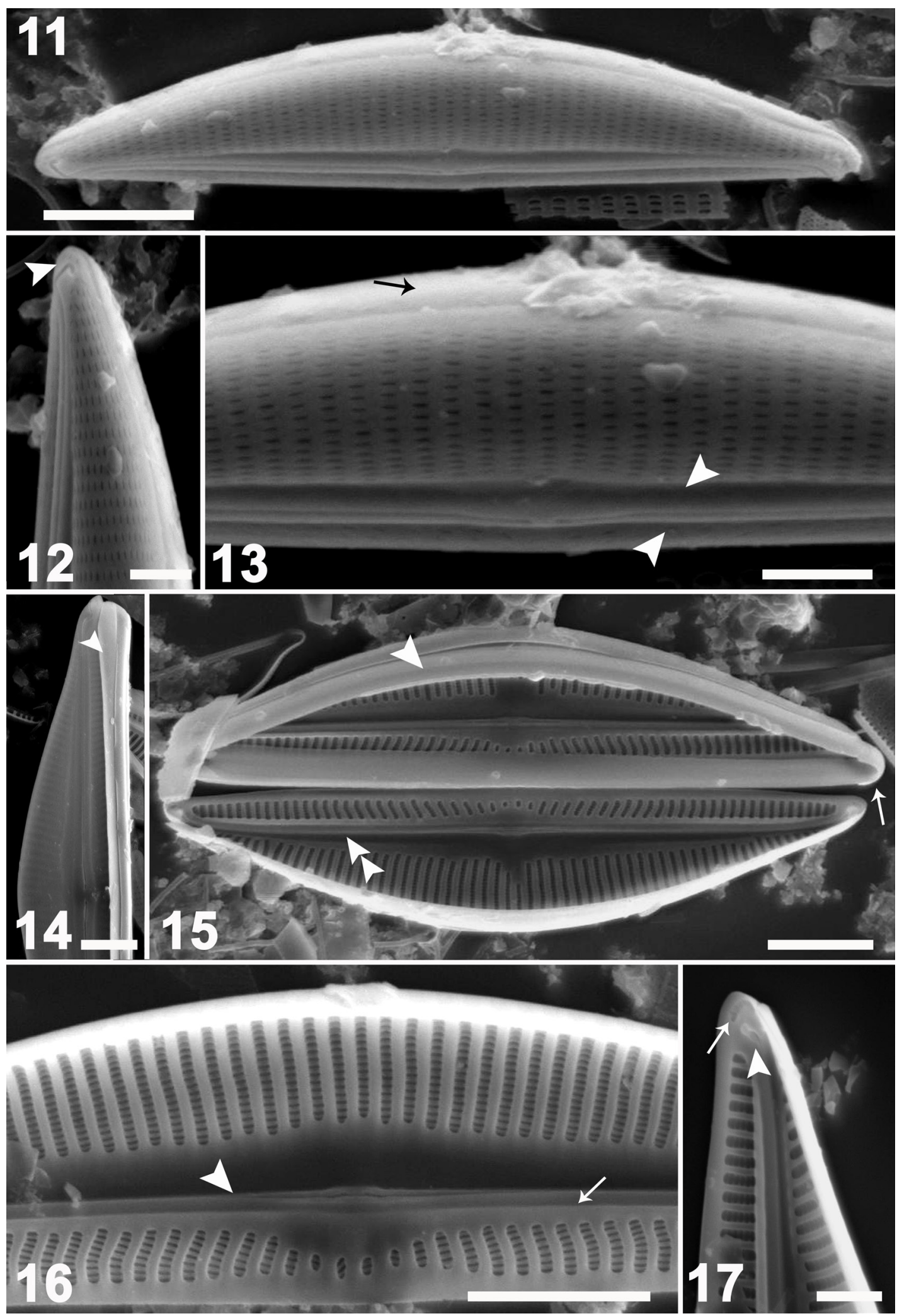

Figs 11-17. SEM images of Seminavis aegyptiaca sp. nov.: (11) external view of the whole valve; (12) external view of the pole showing the dorsally-hooked apical raphe fissure and the simple row of apical pores (arrowhead); (13) close-up view on the valve mid-section showing the ventrally-deflected central raphe endings, two grooves (arrowheads) on opposite sides of the axial raphe sternum, and wide dorsal mantle (arrow); (14-15) details of plain and unornamented valvocopula with a narrow abvalvar segmental element (arrowhead; Fig. 14), much wider central girdle band (arrowhead; Fig. 15), and the small ligulate segment occupying the gaps left at poles (arrow; Fig. 15). Note the rib on which the raphe runs and slightly dorsally-bent near the apices (double arrowheads); (16) internal central portion of the valve showing central raphe endings, the less prominent central nodule, striation pattern and chambering of ventral and dorsal striae. Note also the raphe rib (arrowhead) and the thickened rib-like extension of the ventral lamina (arrow); (17) close-up view on the internal pole region of the valve showing the ventrally bent, terminal helictoglossa (arrowhead) and the apical pit-like depression beyond the helictoglossa containing simple pores that open to the interior (arrow). Scale bars $5 \mu \mathrm{m}(11,14-16), 2 \mu \mathrm{m}(12,13,17)$. 


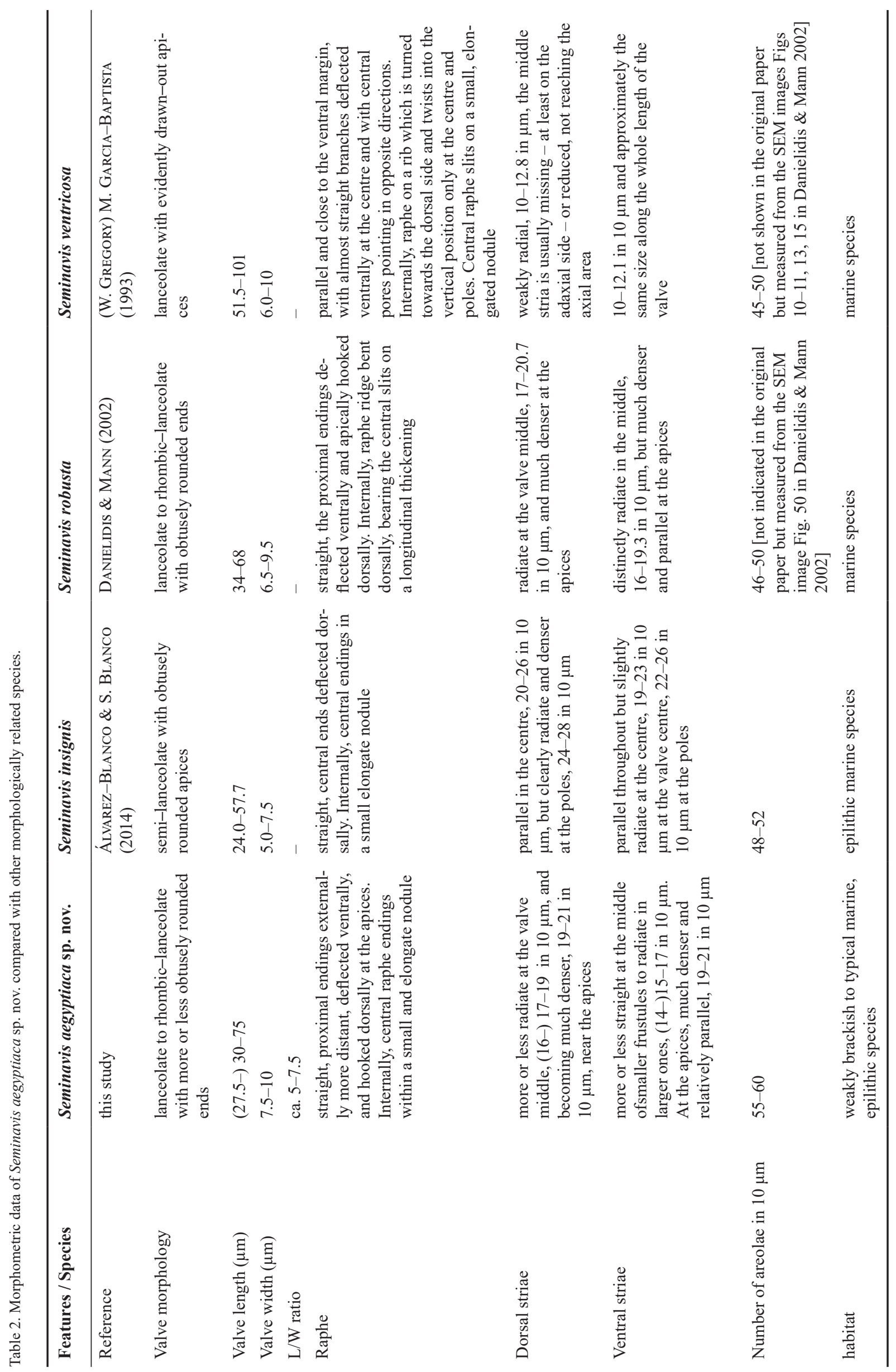


adaxial ends of the striae which open to the cell interior; (7) lower areola density (i.e., $45-50$ in $10 \mu \mathrm{m}$ vs. 55-60 in $10 \mu \mathrm{m}$ for $S$. aegyptiaca); the terminal areola of some dorsal striae being occasionally double and frequently stria discontinuities.

In spite of considerable previous investigations on the Egyptian inland-water diatoms, which were however mainly based on LM observations (e.g., SHAABAN 1994; HAMED 2008; MANSOUR et al. 2015; KHAIRY et al. 2017), it is likely that there are still some Seminavis species (often misidentified as Amphora in the past) overridden in the Egyptian inland-water habitats (A.A.S., unpublished data). These need to be studied well using both LM and SEM to accurately describe their taxonomic characteristics. In agreement with this hypothesis, the study of EL-SHAHED (2006) on the diatom flora of the periphytic assemblages of the west coast of the Red Sea and Suez Gulf revealed two diatom species belonging morphologically to the genus Seminavis but unfortunately there is no information available on their morphotaxonomic features. 'Seminavis sp.1' in his study (EL-SHAHED 2006, plate II, fig. 4) bears some resemblance with $S$. aegyptiaca.

From the ecological point of view, Seminavis aegyptiaca was so far only recorded from the estuary of the River-Nile Damietta Branch, and therefore detailed information about its autecological preferences is still lacking. However, there is a strong indication that it prefers typical marine waters, with only a weak tendency to extend into brackish waters. The preference of Seminavis species identified so far for brackish and marine habitats is well known and reported in the literature (e.g., Round et al. 1990; DANIELIDIS \& MANN 2002, 2003; GARCIA 2007; WACHNICKA \& GAISER 2007; Álvarez-Blanco \& Blanco 2014; TAlgatti et al. 2014; Rioual et al. 2014; De Decker et al. 2018). More interestingly, at the type locality, the new species showed a considerable tolerance to high nutrient $(\mathrm{N}, \mathrm{P})$ levels, as well as to high concentrations of several heavy metals. Nutrient-enrichment tolerance was confirmed also by the co-occurring diatom species.

\section{ACKNOWLEDGEMENTS}

This work was a part of the PhyBiO project funded by the Italian Ministry of Foreign Affairs and International Cooperation (MAECI) to the MUSE Post-Doc Abdullah A. Saber for the academic year 2018/2019. These results were presented at the $24^{\text {th }}$ International Diatom Symposium, Université Laval, Quebec City, Canada, August $21^{\text {st }}-26^{\text {th }}$ 2016. Authors are deeply grateful to the Botany and Microbiology Department, Faculty of Science, Al-Azhar University, Cairo (Egypt), and also to the Botany Department, Faculty of Science, Ain Shams University (Egypt) for providing all facilities used for this research. Also, we are very thankful to Dr Nicola Angeli (MUSE Museo delle Scienze, Limnology \& Phycology Section, Trento, Italy) for his kind support in taking SEM images.

\section{REFERENCES}

AbDel-Satar, A.M.; Ali, M.H. \& Goher, M.E. (2017): Indices of water quality and metal pollution of Nile River, Egypt. - Egyptian Journal of Aquatic Research
43: 21-29.

Álvarez-Blanco, I. \& Blanco, S. (2014): Benthic diatoms from Mediterranean coasts. Bibliotheca Diatomologica, Band 60. - 409 pp., J. Cramer in der Gebr. Borntraeger Verlagsbuchhandlung, Stuttgart.

Bruder, K. \& Medlin, L.K. (2008): Morphological and molecular investigations of naviculoid diatoms. III. Hippodonta and Navicula s.s. - Diatom Research 23(2): 331-347.

Chapman, H.D. \& Pratt, P.F. (1978): Methods of Analysis for Soils, Plant and Water. - 309 pp., University of California, Division of Agriculture Science, California.

Clesceri, L.S.; Greenberg, A.E. \& Eaton, A.D. (2000): Standard methods for the examination of water and wastewater, $20^{\text {th }}$ Edition. - American Public Health Association, Washington DC.

Cox, E.J. (1999): Studies on the diatom genus Navicula Bory. VIII. Variation in valve morphology in relation to the generic diagnosis based on Navicula tripunctata (O.F. Müller) Bory. - Diatom Research 14: 207-237.

Cox, E.J. \& ReID, G. (2004): Generic relationships within the Naviculineae: preliminary cladistic analysis. In: Poulin, M. (ed.): Proceedings of the Seventeenth International Diatom Symposium. - pp. 49-62, Biopress Limited, Bristol.

Danielidis, D.B. \& Mann, D.G. (2002): The systematics of Seminavis (Bacillariophyta): the lost identities of Amphora angusta, A. ventricosa and A. macilenta.European Journal of Phycology 37: 429-448.

Danielidis, D.B. \& MANN, D.G. (2003): New species and new combinations in the genus Seminavis (Bacillariophyta). - Diatom Research 18: 21-39.

Danielidis, D.B.; Ford, K. \& KennetT, D. (2006): Transfer of Amphora eulensteinii to the genus Seminavis D.G. Mann. - Diatom Research 21: 71-80.

De Decker, S.; Vanormelingen, P.; Pinseel, E.; Sefbom, J.; Audoor, S.; Sabbe, K. \& Vyverman, W. (2018): Incomplete reproductive isolation between genetically distinct sympatric clades of the pennate model diatom Seminavis robusta. - Protist 169: 569-583.

EL-Otify, A.M. \& IsKaros, I.A. (2015): Water quality and potamoplankton evaluation of the Nile River in Upper Egypt. - Acta Limnologica Brasiliensia 27: 171-190.

Elrefaey, A.A.; El-Gamal, A.D. \& El-Belely, E.F. (2017): Seasonal dynamics of phytoplanktonic groups in Damietta Branch, River Nile, Egypt. - Egyptian Journal of Phycology 18: 1-20.

EL-Shahed, A.M. (2006): Preliminary study on the diatom flora of coastal periphytic assemblages of the Red Sea and Suez Gulf, Egypt. - Egyptian Journal of Phycology 7: $185-208$

EL-SheEKh, M.M.; Haroon, A.M. \& SAbae, S. (2018): Seasonal and spatial variation of aquatic macrophytes and phytoplankton community at El-Quanater El-Khayria River Nile, Egypt. - Beni-Suef University Journal of Basic and Applied Sciences 7: 344-352.

EN 15708. (2009): Water quality: guidance standard for the surveying, sampling and laboratory analysis of phytobenthos in shallow running water. Ref. No. EN 15708:2009:E. - 26 pp., European Committee for Standardization, Brussels.

Foged, N. (1980): Diatoms in Egypt. - Nova Hedwigia 33: 629-707.

Garcia, M. (2007): Seminavis atlantica Garcia, a new psammic diatom (Bacillariophyceae) from southern Brazilian sandy 
beaches. - Brazilian Journal of Biology 67: 765-769.

Garcia-Baptista, M. (1993): Psammic algae from Praia Azul, Brazil. - Bibliotheca Phycologica 94: 1-167.

GuirY, M.D. \& GuirY, G.M. (2019): AlgaeBase. World-wide electronic publication, National University of Ireland, Galway. http://www.algaebase.org; searched on March $11^{\text {st }} 2019$.

HAMED, A.F. (2008): Biodiversity and distribution of blue-green algae/cyanobacteria and diatoms in some of the Egyptian water habitats in relation to conductivity. - Australian Journal of Basic and Applied Sciences 2: 1-21.

Khairy, H.M.; Shaltout, K.H.; El-Sheekh, M.M. \& Eassa, D.I. (2017): A checklist of diatom species reported from the Egyptian Mediterranean lakes. - Annual Research \& Review in Biology 19: 1-29.

KHEDR, A.A. (1998): Vegetation zonation and management in the Damietta estuary of the River Nile. - Journal of Coastal Conservation 4: 79-86.

Mansour, H.A.; ShaAban, A.M. \& SABER, A.A. (2015): Effect of some environmental factors on the distributions and chlorophyll contents of fresh water phytoplankton of the River Nile before El-Qanater El-Khairia Barrage, Egypt. - Egyptian Journal of Botany 55(1): 45-60.

Negm, A.; Abdel-Aziz, T.M.; Salem, M.N. \& Yousef, W. (2017): Morphology of the Nile River due to a flow rate over the maximum current: case study Damietta branch. - In: Negm, A.M. (ed.): The Nile River. - pp. 239-258, Springer International Publishing, Switzerland.

Rioual, P.; Lu, Y.; Chu, G.; Zhu, B. \& YANG, X. (2014): Morphometric variation of Seminavis pusilla (Bacillariophyceae) and its relationship to salinity in inter-dune lakes of the Badain Jaran Desert, Inner Mongolia, China. - Phycological Research 62: 282-293.

Round, F.E.; Crawford, R.M. \& Mann, D.G. (1990): The diatoms: Biology \& morphology of the genera. - 747 pp., Cambridge University Press, New York,

SALEH, A.I. (2009): Biodiversity of order Naviculales (Bacillariophycophyta) in Egypt. [Ph.D. Thesis]. - 256 pp., Faculty of Science, Ain Shams University, Cairo.

ShaAban, A.S. (1994): Freshwater algae of Egypt. - 150 pp., the United Nations Environmental Programme, National Biodiversity Unit, Biological Diversity of Egypt.

ShaAban, A.S.; Mansour, H.A. \& SAber, A.A. (2012): Phytoplankton in relation to some physico-chemical characteristics of water in Rosetta Branch of River Nile, Egypt. - Egyptian Journal of Botany 52: 483-497.

Talgatti, D.; Bertolli, L.M. \& Torgan, L.C. (2014): Seminavis recta comb. nov. et stat. nov.: morphology and distribution in salt marshes from southern Brazil. - Fottea 14: 141-148.

Talgatti, D.M.; Da Silva, W.J.; Bertolli, L.M. \& Torgan, L.C. (2017): Seminavis norae comb. nov. is the correct name for Seminavis recta. - Phytotaxa 291: 299-300.

Thiers, B. (2018): Index Herbariorum: A Global Directory of Public Herbaria and Associated Staff. New York Botanical Garden's Virtual Herbarium. Available at http://sweetgum.nybg. org/science/ih/

WACHNICKA, A.H. \& GAISER, E.E. (2007): Characterization of Amphora and Seminavis from South Florida, U.S.A. - Diatom Research 22: 387-455.

(C) Czech Phycological Society (2020)

Received July 16, 2019

Accepted October 30, 2019 